\title{
Study of microstructure, maceral and mineral matter in two different coals of the Nepal Himalaya
}

\author{
*Bhupati Neupane ${ }^{1}$ and Bishow Raj Silwal ${ }^{2}$ \\ ${ }^{1}$ Key Laboratory of Continental Collision and Plateau Uplift, Institute of Tibetan Plateau Research, Chinese Academy \\ of Sciences, Beijing 100101, China \\ ${ }^{2}$ Department of Mines and Geology Lainchaur, Kathmandu, Nepal \\ *Corresponding author: bhupati.neupane@yahoo.com
}

\begin{abstract}
The Eocene coals from the western (Tosh coalfield) and central regions (Jhadewa coalfield) of the Nepal Himalaya have been studied under the petrological and the Scanning Electron Microscopes to explain the mode of occurrence of mineral matter and their microstructural relations with organic constituents. As shown by the results of the coal samples, three kinds of coals in diminishing abundance are moderately dull coal, moderately bright coal and bright coal. Distribution of mineral matter in the Eocene coals shows that the bright coal is rare in western Nepal and the moderately bright coal is abundant in central Nepal. Mineral matter in moderately dull coals contains superficial impregnating and cavity filling. Mineral matter in bright coals contains superficial mounting and pore fillings, but in moderately bright coals contains superficial impregnating, cavity filling, and intimate intergrowth. Mineral matters in moderately dull coals, moderately bright coals and bright coals respectively range from 38.27 to 47.12 vol\%, 12.31 and 15.73 vol\%, and 12.31 and $15.73 \mathrm{vol} \%$. The Jhadewa coalfield (central Nepal) contains more macerels than the Tosh coalfield (western Nepal), whereas the Tosh coalfield contains more mineral matter than the Jhadewa coalfield. The results indicate two different origins for coal deposits from two different regions.
\end{abstract}

Keywords: Eocene coals, Jhadewa coalfield, Tosh coalfield, Micro-structural components, Mineral matter

Paper Received: 24 Feb 2018

Paper Accepted: 16 May 2018

\section{INTRODUCTION}

Coal comprises two different classes of materials. The first one is organic component or maceral, and the second one is a range of minerals and other inorganic constituents, broadly referred to as mineral matter (Ward, 2002). The organic components are essential for the nature of coal (e.g. rank and type), and to its value in different utilisation purposes (e.g. Taylor et al., 1998). The macerals are significant for several reasons, e.g. energy output on combustion, metallurgical processing, in-situ methane absorption capability, and an alternative hydrocarbon source (Ward, 2002). The mineral matter in coal is a product of processes associated with peat accumulation and rank advance, as well as changes in subsurface fluids and other aspects of sediment diagenesis (Gary et al., 1972).

The microstructural relations of mineral matter with organic constituents have genetic significance (syngenetic or epigenetic in origin) and also have practical applications (Singh et. al., 2015). A number of techniques are available for evaluating organic and inorganic constituents of coals. Greer (1977, 1978), and Saunders (1980) have established the nature of mineral contaminations in coal with the help of Scanning Electron Microscopy (SEM). SEM imaging is a useful tool for studying microcracks and macropores (size range between $10 \mu \mathrm{m}$ and $100 \mu \mathrm{m}$ ). Microcracks and micropores play important roles in the transport and permeation of gas, and therefore are the primary contributors of the overall permeability (Pan et al., 2014).

In the Nepal Himalaya, few works on microstructures and the chemical and mineral composition of coal carried out by Sharma, (1977), Aryal et al. (1997), Aryal (2000), Paudyal and Sah (2004), and Neupane et al. (2017b), are known to exist. In the present study, the coal samples from two different coalfields; Tosh coalfield (Dang, western Nepal) and Jhadewa coalfield (Palpa, central Nepal) have been studied (Fig. 1). All of the coal seams both exposed or under production were sampled. Using geochemical analysis and SEM, an attempt has been made to understand the microstructural relation, paleo-marine depositional environment of the Eocene basin of this region by Neupane et al. (2017c). This research compared only, microstructure, macerals and mineral matter in two different coalfields. 


\section{GEOLOGICAL SETTING}

Nepal lies in the central region of the Indian subcontinent (Fig. 1). The coalfields of the foreland basin are distributed in the different regions of the Nepal Himalaya; Surkhet (Midwestern), Dang (Midwestern), Palpa (western) and Barahachhetra (Eastern) (Fig. 1). The Eocene coal deposits of the Dang and Palpa regions are believed to have developed in basins located along the Lesser Himalaya (Sakai, 1989; Dhital, 2015; Neupane et al., 2016). In the Nepal Himalaya, coal occurrence has been recorded from four stratigraphic units; the Quaternary lignite in the Kathmandu valley, the coal of the subHimalaya, the Gondwana coal of eastern Nepal, and the Eocene coal of Western and mid-Western Nepal (ESCAP, 1993; Aryal, 2000). The present study mainly focused on the two important coalfields both of which are Eocene deposits; Tosh coalfield (Dang District) and Jhadewa coalfield (Palpa District).

\section{Tosh coalfield (Northern Dang)}

The study area lies in the Tosh area of the Dang District, western Nepal and belongs to the Lesser Himalaya (Fig. 1) and probably belongs to Eocene. Based on the stratigraphy and fossil content, the coalfield area is the part of the Tosh Group, which disconformably overlies the Gwar Group (i.e., Ranibas Formation; Dhital, 2015). The Tosh Group is stratigraphically divisible into two mappable units; the Sattim Formation and the Dubring Formation in an ascending order. The coalfield bearing Sattim Formation is underlain by the Ranibas Formation and overlain by the Dubring Formation (Fig. 2). The Sattim Formation is divisible into three members, lower, middle and upper.

The lower member consists of conglomerate, dark brown to red shale, green shale and white quartzose sandstone. They also comprise some thin and discontinuous sandstone layers. The middle member consists of various coal seems, which occur as thin beds, lenses, and stringers at various levels, composed mainly of many quartz arenites and shale cycles (Dhital, 2015). The coal deposits extend from the Tosh Area in the NE to Khara in the NW (Fig. 2). This belt is characterized by a series of imbricate overthrusts. The upper member comprises grey-green to pink-gray and mottled argillaceous limestones, shale, and sandstone sequence. Limestones are purple to green calcareous argillite with Nummulites and Assilina fossils whereas brown shales include many dispersed bivalves.

Within the coalfield of Tosh, coal seams are intercalated with white quartzose sandstone and carbonaceous shale. Due to the imbricate faulting and folding, the thickness of the coal seams varies among different regions (i.e., 1.0

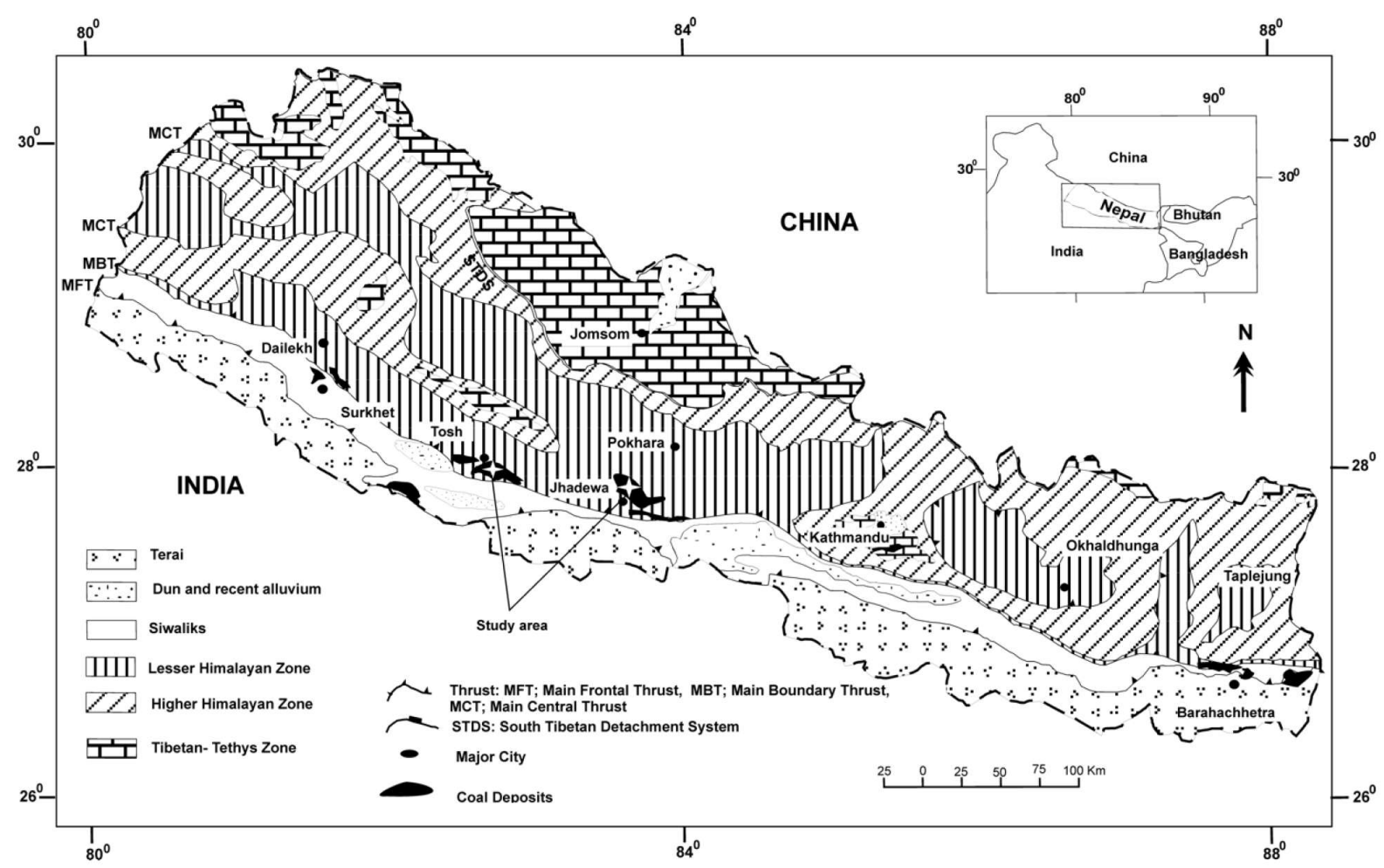

Fig. 1: Geological map of Nepal showing the location of the study areas (Modified after Upreti, 1999). 


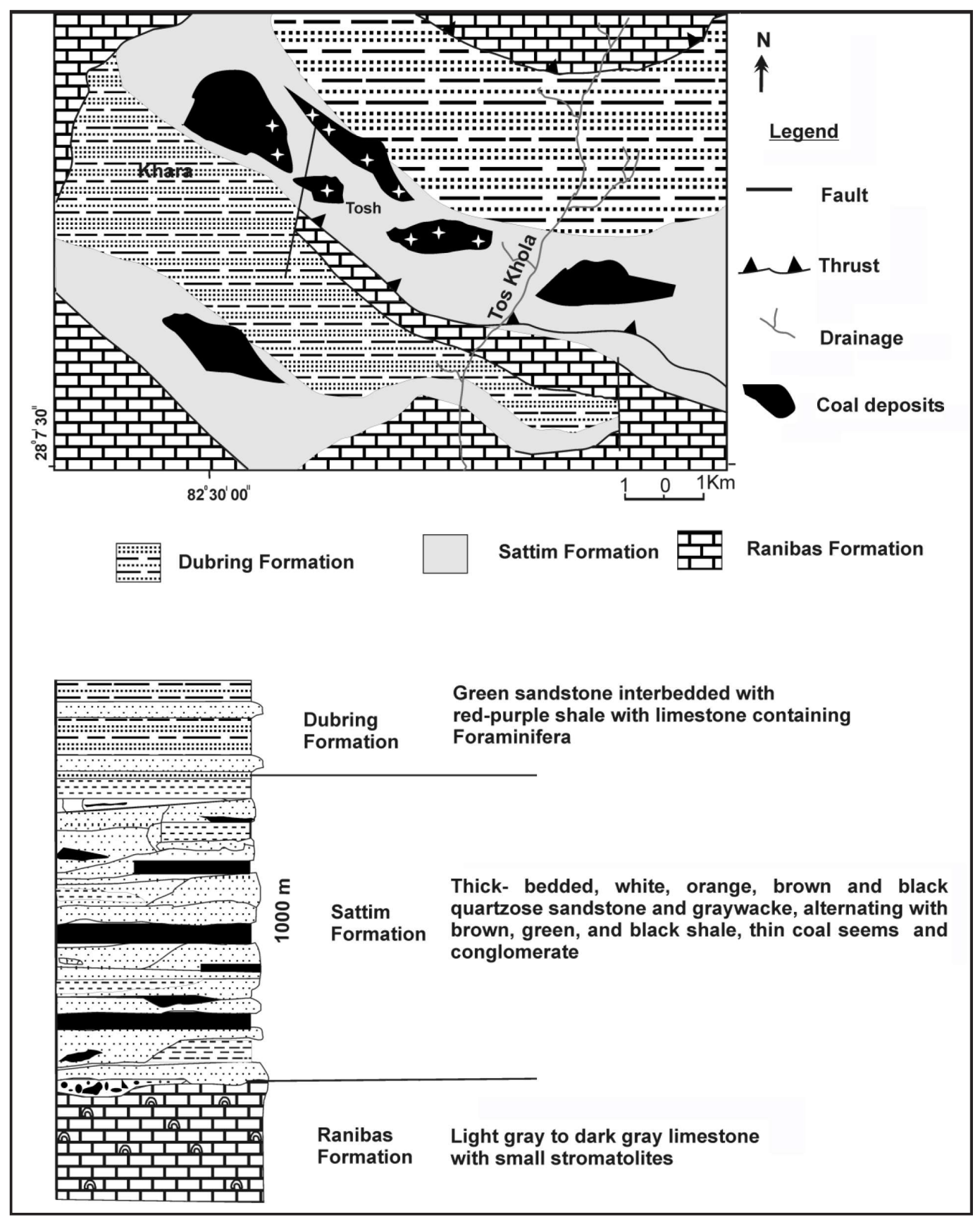

Fig. 2: Simplified geological map of the Tosh coalfield (modified after Neupane et al, 2017c)

$\mathrm{m}-7.5 \mathrm{~m}$ ). There are evidences of several local mining holes occurring over $10 \mathrm{~m}$ to several kilometers.

\section{Jhadewa Coalfield}

The study area is located in the Palpa district, central Nepal (Fig. 1). The coal-bearing strata occur in the Bhainskati Formation (i.e., upper Gondwana) which belongs to deposited as Eocene (Neupane et al., 2017a). Bhainskati Formation is conformably overlain Amile Formation and underlies Dumri Formation largely consists of coal, shale, dark and muddy limestone and hematite beds. The shale Formations are composed of green-reddishpurple shale with pencil cleavage and black shale beds contain pyritized wood fragments. A fossiliferous horizon, coquinoid, is present in this Formation. It contains abundant bivalves, gastropods, and foraminifera (Sakai, 1983). Particularly, the presence of Nummulites $s p$. indicates an Eocene age for Bhainskati Formation. Given the general perceived Indo-Asian collision at 55 to $50 \mathrm{Ma}$, this Formation is believed to be deposited after the continental collision (Neupane et al., 2017b). 


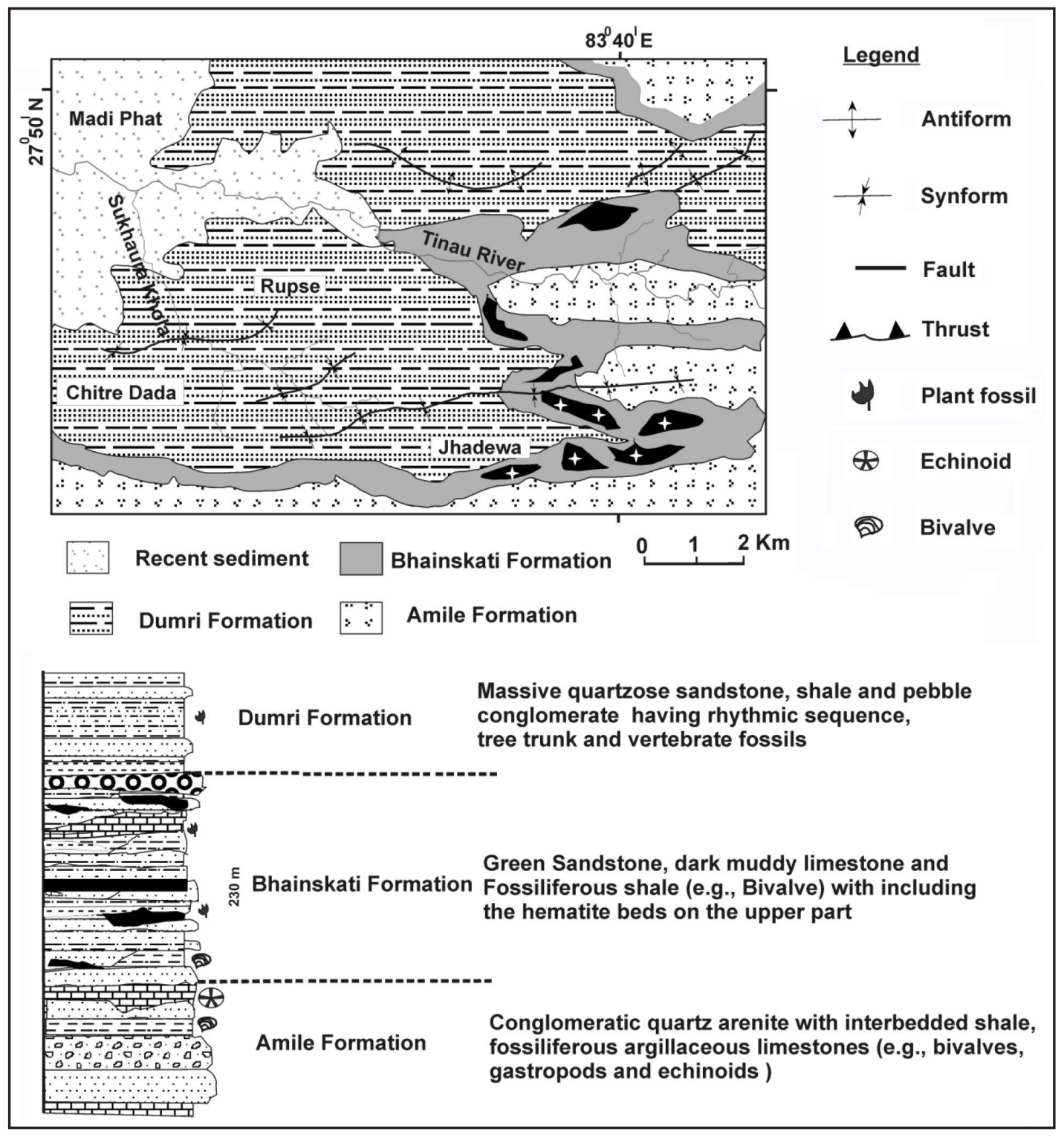

Fig. 3: Simplified geological map of the Jhadewa coalfield

The coalfield of Jhadewa is bounded by different fold and small-scale fault. Presently, there are seven active coal mining sites, which produce 5-6-ton coal per day. The coalbearing horizon is highly sheared with abnormally low fuel ratio, and the thickness ranging from 1.1 to $3.5 \mathrm{~m}$. The coal seam is fairly tabular and continuous whereas the imbricate faults occur repeatedly in the study area.

\section{MATERIALS AND METHODS}

Two different regions of the Eocene basin were selected for sample collection. A total of 11 coal samples were collected directly from the underground coal mines and outcrop coal seams in two different basins. Six samples were chosen from the western regions (depth ranges from $305 \mathrm{~m}$ to $315 \mathrm{~m}$; Fig. 2) of the basin, and the remaining five were taken from the central region (depth ranges from 360 $\mathrm{m}$ to $366 \mathrm{~m}$; Fig. 3). All Eocene coal samples were collected from the working faces of the coal seams. The Eocene coals are non-banded (at trial) in nature and their macroscopic features were examined according the scheme proposed by Schopf (1960). According to the macroscopic characteristics, the Eocene coals were distinguished into three lithotypes, i.e., bright, moderately bright, and moderately dull. Each of them was subjected to the optical microscopic examination as well as SEM analysis. For the microscopic study, coal samples of all three lithotypes were crushed to 18 mesh size coal particles. The particulate coal 
mounts (coal pellets) were prepared by using the cold setting material. Afterward, the microscopic study has been carried out on an advanced petrological microscope (ZEISS Axio Scope A1). The identification criteria were imported from the International Committee for Coal and Organic Petrology (ICCP, 1994, 1998; Taylor et al., 1998).

SEM having ability to magnify object as more as 100,000 times, can help to better understand the micromorphology on a solid surface and analyze the fracture forms and internal structure of materials (Baisheng et al., 2015). SEM is one of the most important techniques for the study of the coal ultra-structure and is being applied to understand the modes of occurrences (mineral-maceral microstructural relationship) of mineral matter in coals.

Due to the need of qualitative and quantitative analysis of organic and inorganic constituents of coals, which was conventionally performed by a light microscope under white/fluorescent reflected light (Singh et al., 2015), the coal samples required to go through a number of stages of grinding and polishing. For the SEM study, individual lithotypes were selected from the coal samples (Table 1), and chips of $\sim 0.1 \mathrm{~m}$ in size were separated from each lithotype with the help of forceps, chisel, and hammer. Then, the obtained chips are washed with alcohol to remove the superficial dust and then mounted on aluminum stubs using silver paste. Finally, they were coated with gold in the vacuum machine that made the samples conducting, which was necessary for the non-metallic substance that was subjected to SEM investigations. All the prepared coal lithotype chips were examined under a JEOL (model JSM840A), high-performance computer-controlled scanning electron microscope (SEM).

SEM having ability to magnify object as more as 100,000 times, can help to better understand the micromorphology on a solid surface and analyze the fracture forms and internal structure of materials (Baisheng et al., 2015). SEM is one of the most important techniques for the study of the coal ultra- structure and is being applied to understand the modes of occurrences (mineral-maceral microstructural relationship) of mineral matter in coals.

Due to the need of qualitative and quantitative analysis of organic and inorganic constituents of coals, which was conventionally performed by a light microscope under white/fluorescent reflected light (Singh et al., 2015), the coal samples required to go through a number of stages of grinding and polishing. The SEM study of unpolished coal lithotypes exposed the coal-mineral micro structural feature as well as mineral matter occurring in superficial pores, cleats, cracks, and fissures of the coal particles. For the SEM study at different magnifications, microstructural features were recorded, photographed and the quantitative assessment of mineral matter and coal-mineral microstructural relations were carried out visually. The visual estimation was based upon the extent of the surface area in the view covered by mineral matter with microstructural relation with organic matter and the counts where similar features appeared.

\section{RESULT AND DISCUSSION}

\section{Petrographic features of mineral matter}

Clay minerals (i.e., fine, black and granular) are mostly dominant apart from carbonate and sulfide in the microscopic studies (Fig. 4). They appear as groundmass and also occupy fissures, cracks, cleats, and cell lumens of fusinite, semifusinite, and sclerotinia. Carbonates occur as groundmass, stringers, and fissure-filling whereas pyrites occur in several forms, such as disseminated particles, blebs, discrete grains, framboids, and massive replacement and fissure-filling. The result of coal samples from central Nepal (Jhadewa coalfield) contains bright and moderately bright coal and that of western Nepal coal (Tosh coalfield) contains moderately dull coal (Table 1). Distribution of mineral matter in the lithotype of the Eocene coals shows that the bright coal is rare in western Nepal whereas the moderately bright coal and bright coal are abundant in central Nepal.

In bright coals, a total mineral matter content varies between 5.95 and 7.35 vol\%. Among them, sulfide minerals range from 0.13 to $0.18 \mathrm{vol} \%$, carbonate is nil and clay varies from 5.77 to $7.22 \mathrm{vol} \%$. The total macerals range from 92.65 to 94.05 vol\% (Table 1 ). In moderately bright coal, mineral matter varies from 12.31 to $15.73 \%$, the sulphide mineral from 0.19 to $0.45 \mathrm{vol} \%$, clay from 12.12 to $15.30 \mathrm{vol} \%$ and maceral from 84.27 to $87.69 \mathrm{vol} \%$. In moderately dull coal, the concentration of total mineral matter ranges from 38.27 to $47.12 \%$, the sulphide mineral from 2.24 to $4.44 \mathrm{vol} \%$, clay from 34.69 to $43.56 \mathrm{vol} \%$, and maceral from 52.88 to $61.73 \mathrm{vol} \%$. In bright coal, total mineral matter varies from 5.95 to $7.35 \%$ whereas, maceral content varies from 92.65 to $94.05 \mathrm{vol} \%$.

\section{Bright coal}

The bright coal band contains inherent cracks and micro-fissures (Fig. 5a) which may provide the path for hydrocarbon migration. The mineral occurs as pore filling 
Table 1: Maceral composition of coals from the Nepal Himalaya

\begin{tabular}{|c|c|c|c|c|c|c|c|c|}
\hline & \multicolumn{4}{|c|}{ Organic components } & \multicolumn{3}{|c|}{ Inorganic components } & \multirow[t]{2}{*}{ Coal Classification } \\
\hline & $\begin{array}{c}\text { Vitrinite } \\
(\%)\end{array}$ & $\begin{array}{l}\text { Intertinite } \\
\text { Group (\%) }\end{array}$ & $\begin{array}{l}\text { Sample } \\
\text { ID }\end{array}$ & $\begin{array}{c}\text { Total } \\
\text { macerals } \\
(\%)\end{array}$ & $\begin{array}{l}\text { Clay } \\
(\%)\end{array}$ & $\begin{array}{c}\text { Sulfide } \\
(\%)\end{array}$ & $\begin{array}{c}\text { Total Mineral } \\
\text { matter } \\
(\%)\end{array}$ & \\
\hline${ }^{1} \mathrm{DC} 02$ & 67.88 & 15.66 & 1.17 & 85.30 & 14.25 & 0.45 & 14.70 & Moderately bright coal \\
\hline $\mathrm{DC} 03$ & 70.32 & 11.45 & 1.89 & 84.27 & 15.30 & 0.43 & 15.73 & Moderately bright coal \\
\hline DC04 & 79.98 & 5.24 & 2.03 & 87.69 & 12.12 & 0.19 & 12.31 & Moderately bright coal \\
\hline DC05 & 58.04 & 1.02 & 1.11 & 60.17 & 37.59 & 2.24 & 39.83 & Moderately dull coal \\
\hline DC07 & 88.45 & 2.02 & 1.56 & 92.65 & 7.22 & 0.13 & 7.35 & Bright Coal \\
\hline $2 \mathrm{TC} 01$ & 81.66 & 9.36 & 3.03 & 94.05 & 5.77 & 0.18 & 5.95 & Bright Coal \\
\hline $\mathrm{TC} 02$ & 58.04 & 1.02 & 1.11 & 60.17 & 37.59 & 2.24 & 39.83 & Moderately dull coal \\
\hline $\mathrm{TC} 03$ & 52.97 & 0.56 & 0.55 & 54.08 & 42.76 & 3.16 & 45.92 & Moderately dull coal \\
\hline $\mathrm{TC} 04$ & 56.80 & 1.68 & 2.86 & 61.73 & 34.69 & 3.58 & 38.27 & Moderately dull coal \\
\hline TC05 & 53.88 & 2.09 & 3.23 & 59.20 & 37.91 & 2.89 & 40.80 & Moderately bright coal \\
\hline TC08 & 49.89 & 3.88 & 4.22 & 57.99 & 37.57 & 4.44 & 42.01 & Moderately dull coal \\
\hline TC09 & 49.99 & 1.55 & 1.34 & 52.88 & 43.56 & 3.56 & 47.12 & Moderately dull coal \\
\hline
\end{tabular}

${ }^{1}$ DC: Jhadewa coalfield, central Nepal; ${ }^{2} \mathrm{TC}$ : Tosh coalfield, western Nepal.
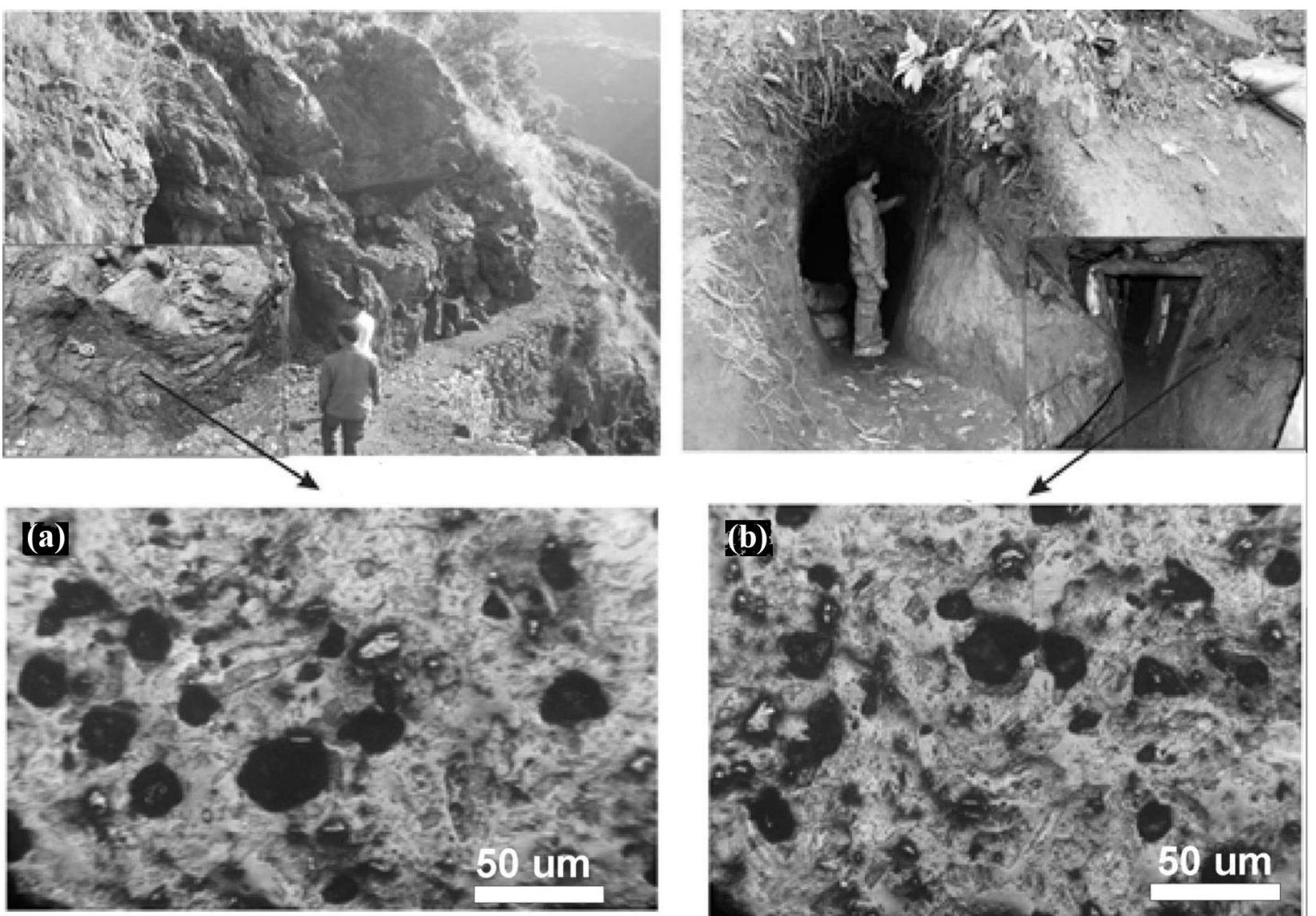

Fig. 4: Showing coal deposits (upper section) with representative photomicrographs (down section) of macerals of (a) Tosh coalfield and (b) Jhadewa coalfield 

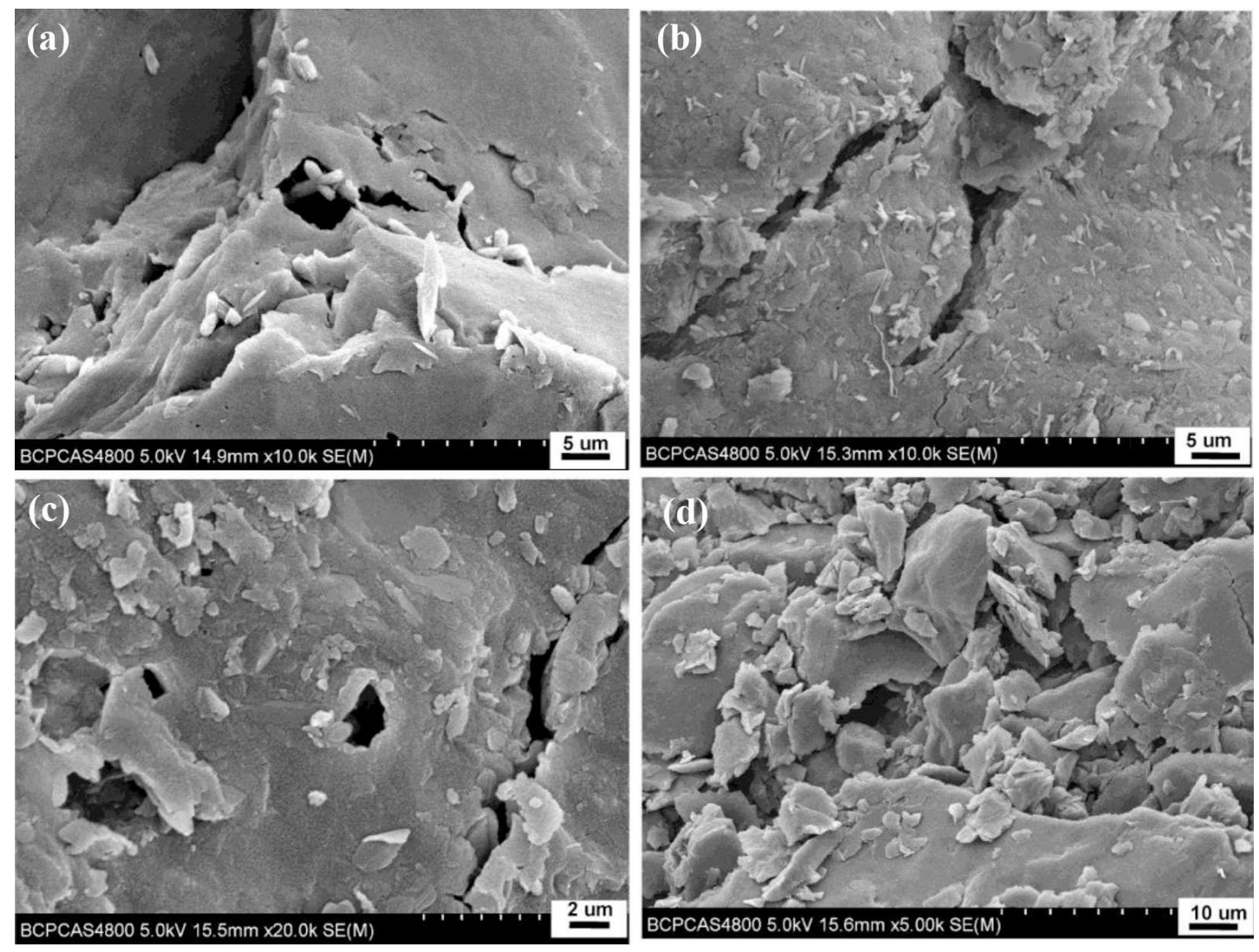

Fig. 5: SEM image of "bright coal" bands showing minerals and their micro-structural relations. (a) micro fissure showing the migration path of hydrocarbon, (b) highly porous with wedge-shaped pores, (c) the telnitic cavities and conchoidal fracture, and (d) A cluster of framboidal pyrite.

(Fig. 5b) with few of crystalline clay mineral (illite). The selenite bands (Fig. 5c) with conchoidal fracture are also seen. The framboidal pyrite (Fig. 5d) is commonly observed in the bright coal bands. The mineral matter is rare to very rare in this lithotype (Table 1).

\section{Moderately bright coal}

According to the SEM of the moderately bright coal, the common mineral-coal microstructural features are: cavity filling (Fig. 6a), micro crack and bottle-shaped pores (Figure 5b), and pore filling (Fig. 6c). These coal bands are highly porous in nature (Fig. 6d) whereas the mineral matter is moderate in this lithotype (Table 1).

\section{Moderately dull coal}

The results of SEM image of moderately dull coal (Fig. $7 a)$ appears as a compact granular mass. The mineral matter occurs as cavity filling (Fig. 7b), cluster of framboidal pyrite (Fig. 6c), and cavity filling (Fig. 7d). The micro fissures may act as channels for the migration of hydrocarbon. The concentration of mineral matter ranges from abundant to less abundant (Table 1).
According to the SEM, the minimum mineral matter occurs in bright coals followed by moderately bright coals and moderately dull coals. The occurrence of microstructures depends upon mineral matter and is partly inherent and induced during the development of peat (Nie et al., 2015). Microstructures like superficial pore, fissure fillings, superficial mounting, and cavity filling all point towards the association with organic matter at a later stage.

A bulk microstructure, i.e. homogeneously distributed network of small crystallites, exhibits the presence of minerals, which show luminous and non-luminous features, in the organic matrix (Manoj et al., 2009). Different luminosities illustrate different elements. The bright luminosity illustrates the occurrence of aluminum, potassium or sodium, and the dark luminosity reflects the presence of chalcophiles (Shakirullah et al., 2006). The incidences of pyrite as framboids, blebs, disseminated, and massive replacement specify their induction during the early stage of peat formation (Singh et al., 2015). Similarly, the fissure and cleat filling indicate epigenetic mineralization. 

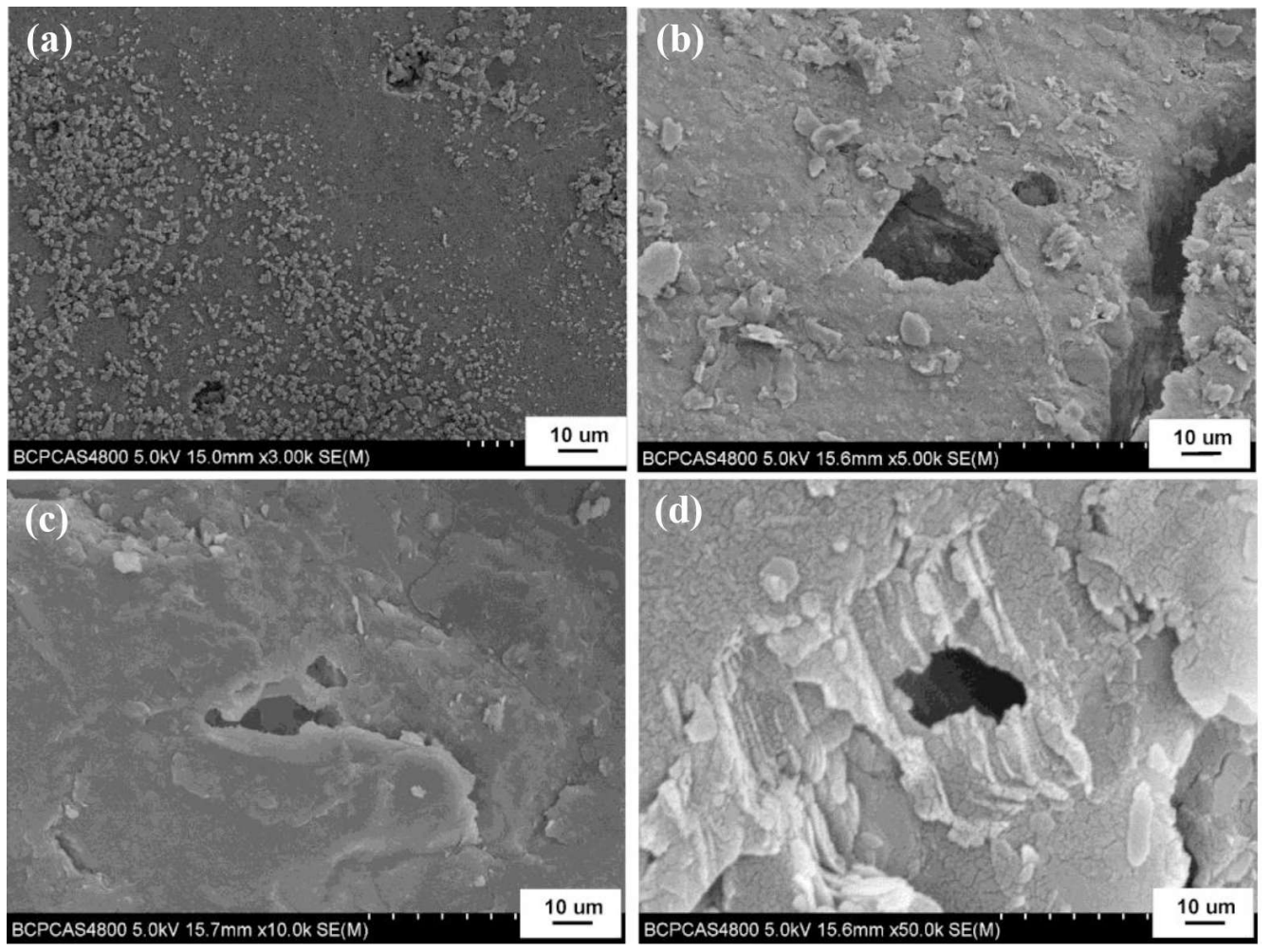

Fig. 6: SEM image of moderately bright coal bands showing minerals occupying the micro-structures. (a) clay minerals (illite) and unfilled cell cavities, (b) micro-crack and bottle-shaped pores, (c) highly porous nature of moderately bright coal, (d) intimate intergrowth of mineral matter.
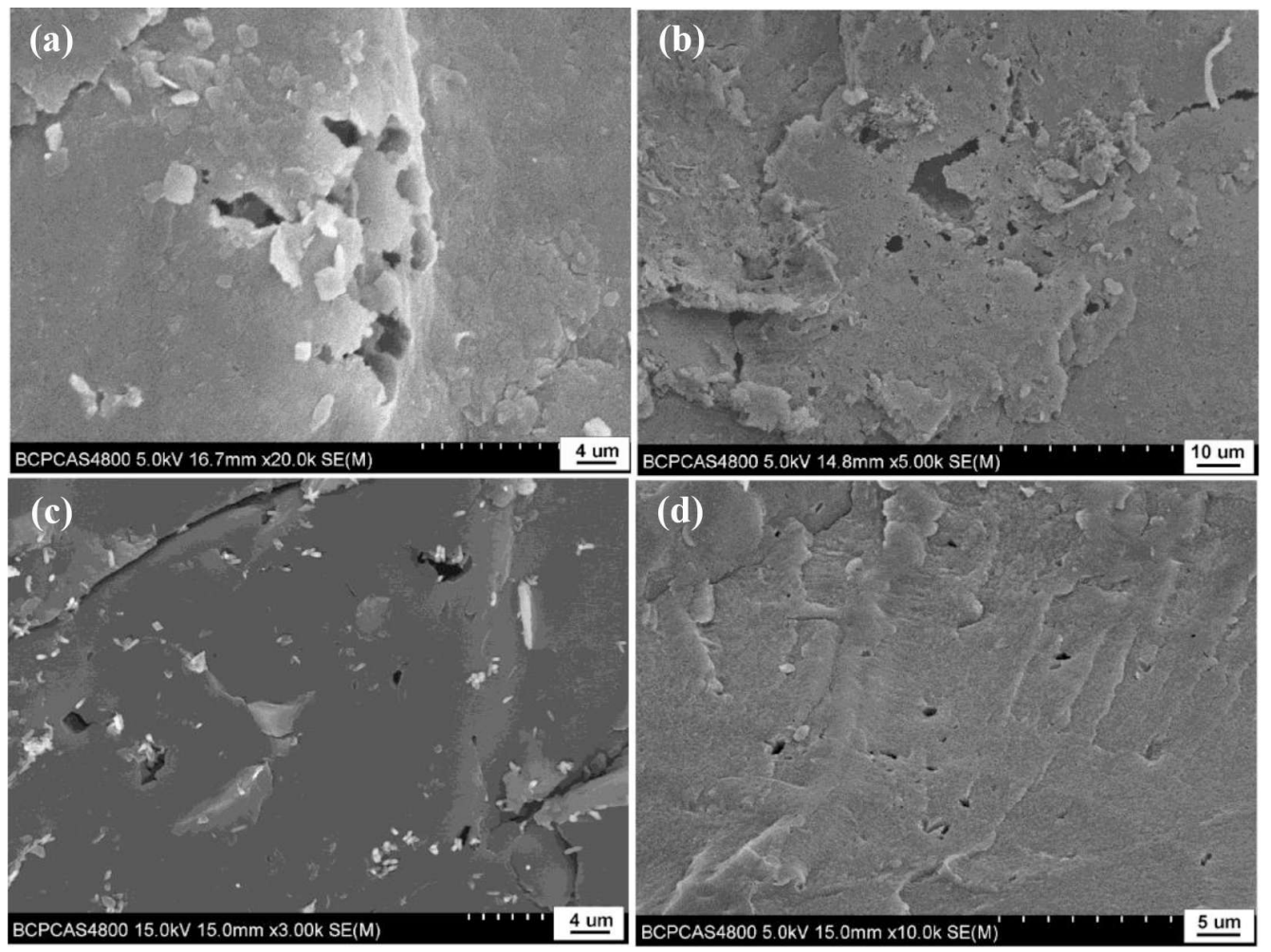

Fig. 7: SEM image of moderately dull coal bands showing minerals and structures. (a) moderately porous nature of moderately dull coal, (b) clay minerals (illite) and unfilled cell cavities, (c) cluster of framboidal pyrite, and (d) cavity filling of mineral matter in moderately dull coal. 


\section{CONCLUSION}

The SEM technique was applied to study of microstructure, macerals and mineral matter in the two different coals of the Nepal Himalaya. These results indicated that the mineral matter in the Eocene coals of Jhadewa occurs as fissures, deep intergrowth, massive impregnation, cavity filling, superficial filling of pores, and superficial mounting. The SEM data of Eocene coal showed that mineral matter is rare in bright coal, less abundant in moderately bright coal, and abundant in moderately dull coal, showing the order of abundance of mineral matter expressed as: bright coal $<$ moderately bright coal $<$ moderately dull coal. The above results indicate that the western Nepal coal (Tosh coalfield) contains more mineral matter (moderately dull coal) than central Nepal coal (Jhadewa coalfield). The Eocene series (Bhainskati Formation) in Nepal Himalaya spread in different regions (i.e., eastern, central and western). Therefore, different properties of two different coalfields of Nepal Himalaya suggest the depositional environment for coal deposit in two different basins might be different in the Eocene time.

\section{ACKNOWLEDGEMENTS}

We thank Professor Yiwen Ju for financial support and Peking University for providing laboratory facility. Prof. Dr. Megh Raj Dhital and Dr. Prakash Das Ulak provided useful suggestions for this research and field guidance as well. Constructive comments and suggestions from two anonymous reviewers are greatly acknowledged.

\section{REFERENCES}

Aryal, R.K., 2000, Current Status of Coal Deposits of Nepal. Nepal Geological Society v.17, pp. 77-80.

Aryal, R.K., Shrestha, U.B., and Khadha, R.K., 1997, A report on Coal Drilling of Tosh Area. DMG, Nepal, pp. 1-13.

Dhital, M.R., 2015, Geology of the Nepal Himalaya: Regional Perspective of the Classic Collided Orogen: Cham, Springer International Publishing Switzerland.

ESCAP., 1993, Geology and Mineral Resources of Nepal. Explanatory Brochure, United Nations, 107P.

Gary, M., McAfee, R., Wolf, C.L. Eds., 1972, Glossary of Geology. American Geol. Institute, Washington, DC, 805p.

Greer, R.T., 1977, Coal microstructure and the significance of pyrite inclusion. Scanning Electron Microscopy I: pp. 79-93

Greer, R.T., 1978, Pyrite distribution in coal. Scanning Electron Microscopy II: pp. 621-626
Manoj, B., Kunjomana, A., and Chandrasekharan K., 2009, Chemical leaching of low-rank coal and its characterization using SEM/EDAX and FTIR. Journal of Minerals and Materials Characterization and Engineering, pp. 821-832.

Neupane, B., Ju, Y., Tan, F., Baral, U., Ulak, P.D., and Sun, Y., 2017a, Cenozoic tectonic evolution of the Tibetan Plateau-the Nepal Himalaya and the provenance of their foreland basins.ÊGeological Journal, v. 52(4), pp.646-666.

Neupane, B., Ju, Y., Allen, C.M., Ulak, P.D., and Han, K., 2018. Petrography and provenance of Upper Cretaceous-Palaeogene sandstones in the foreland basin system of Central Nepal. International Geology Review,Êv. 60(2), pp.135-156.

Neupane, B., Ju, Y., Silwal, B.R., Singh, P.K., and Huang, C., 2017, Structural investigations of Eocene coals from foreland basin of central Nepal Himalaya. Energy Exploration and Exploitation, v. 35(6), pp.713-733.

Nie, B., Liu, X., and Yang, L., 2015, Pore structure characterization of different rank coals using gas adsorption and scanning electron microscopy. Fuel, pp. 908-917.

Pan, L., Chortos, A., Yu, G., Wang, Y., Isaacson, S., Allen, R., Shi, Y., Dauskardt, R., and Bao, Z., 2014, An ultra-sensitive resistive pressure sensor based on hollow-sphere microstructure induced elasticity in conducting polymer film. Nature communications,v. 5, pp. 3002.

Sakai, H., 1983, Geology of the Tansen group of the Lesser Himalaya in Nepal. Mem. Fac. Sci. Kyushu University, v. 25 , pp. $27-74$.

Sakai, H., 1989, Rifting of the Gondwanaland and uplifting of the Himalayas recorded in Mesozoic and Tertiary fluvial sediments in the Nepal Himalayas. Sedimentary Facies in the Active Plate Margin, pp. 723-732.

Saunders, K.G., 1980, Microstructural studies of chlorine of some British coals. J. Energy Inst., v. 109, pp. 110-115.

Shakirullah, M., Ahmad I., and Khan, M.A., 2006, Leaching of Minerals in Degari Coal. Journal of Minerals and Materials Characterization and Engineering, v. 5, pp. 131-142.

Singh, A.K., Singh, M.P. and Singh, P.K., 2015, Microstructural relation of macerals with mineral matter in Eocene coal. Energy Sources, Part A: Recovery, Utilization, and Environmental Effects, v. 37(10), pp.1089-1097.

Taylor, G.H., Teichmuller, M., Davis, A., Diessel, C.F.K., Littke, R., and Robert, P., 1998, Organic Petrology. Gebruder Borntraeger, Berlin, 704p.

Upreti, B., 1999, An overview of the stratigraphy and tectonics of the Nepal Himalaya: Journal of Asian Earth Sciences, v. 17, pp. 577-606. doi:10.1016/S1367-9120(99)00047-4

Ward, C.R., 2002, Analysis and significance of mineral matter in coal seams, International Journal of Coal Geology, v. 50(1), pp.135-168 
